\title{
Como Estão as "Manchas Ácidas" no Brasil?
}

\section{A. OSWALDO SEVÁ FILHO*}

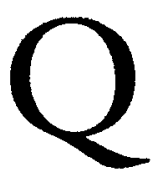

uando apresentei ao Instituto de Estudos Avançados o projeto de pesquisa "Risco Tecnológico e Natureza Alterada", previa a elaboração de um pequeno informe técnico sobre a polêmica em torno da chuva ácida, que sabíamos ser algo cada vez mais importante em alguns países e em algumas regióes mais industrializadas na Europa e na América do Norte, e que apenas se esboçava no Brasil, a partir dos casos de denúncia comprovada em Cubatáo e na área carbonífera de Santa Catarina.

Entretanto, desde entáo vem se tornando mais clara a mudança de patamar, a inflexão qualitativa e espacial que a poluição chamada de atmosférica atingiu no país. No mínimo, caberia a um estudioso universitário acreditar nas pistas sugeridas pelas reclamaçóes locais - nas áreas de refinarias e de algumas siderúrgicas e metalúrgicas, nas áreas de centrais termo-elétricas, nas vizinhanças das fábricas de celulose, por exemplo.

Como os processos desencadeados são em parte latentes, suas repercussōes se manifestarão a médio e longo prazo; e como são em parte cumulativos e sinérgicos, os efeitos e sequelas seráo resultados de combinaçóes de alguns processos distintos. Por isto, a própria relação de causalidade, tão cara para o método científico, não está ou não pode ser táo clara e táo exata. Fica sempre a impressão de que, de fato, o problema não existe, ou de que o problema náo é assim táo grave.

Os projetos recentes de novas centrais térmicas queimando carvão em Santa Catarina e no Rio Grande do Sul, ou queimando resíduos de processamento de petróleo, ao lado das refinarias de Paulínia e de Sáo José dos Campos, em São Paulo, os projetos de ampliação e de instalação de pólos petroquímicos na Baixada Fluminense, na regiáo de Porto

* A. Oswaldo Seva Filho é professor na área de Planejamento Energético da Faculdade de Engenharia Mecânica da Unicamp. No biênio 1989-90, realizou pesquisa de pós-doutorado no IEA, com o apoio da Ford Foundation. 
Alegre e no Recôncavo baiano, e alguns projetos de mineração e de metalúrgicas prevendo o processamento de materiais piritosos (com teores importantes de enxôfre), ou a utilização de reaçōes químicas e eletroquímicas por meio de compostos ácidos, tudo isto nos impelia, e a alguns outros colegas, a re-considerar a questáo da acidez.

Aparentemente, o debate técnico tende para o campo das correçóes possíveis, através de beneficiamentos adicionais do carvão, do petróleo ou dos minérios, e através da instalaçăo de filtros, neutralizadores ou catalizadores de gases nos tubos de descargas dos motores e nas chaminés das caldeiras e dos fornos. Todavia, o impasse está dado pela qualidade baixa ou péssima de uma boa parte destes combustiveis e destes minérios. No caso do carvão mineral brasileiro, este é um estigma do qual não se pode escapar facilmente; no caso do petróleo, vale registrar que o que é aqui extraído, em geral tem baixo teor de enxofre e de outros componentes prejudiciais, mas, o que é importado é exatamente o contrário.

Prosseguir um estudo neste contexto, e municiar a opinião pública com as advertências e previsóes necessárias, pode ser visto como "remar contra a corrente", ou até mesmo como "levantar uma lebre inexistente", e ainda, como "alarmismo" . Ora, a corrente, alhures, vai no rumo das reformas, a lebre existe em várias situaçóes e pode existir nas situaçóes similares, e, diante de um processo latente e em parte desconhecido, parece mais saudável ser alarmista do que ser omisso.

Assim, tomamos como dado de partida que está de fato havendo uma acidificação, senão do planeta todo, mas de várias regiōes importantes, e que isto é um campo de fortes pressões:

- uma pressáo ambiental propriamente dita, uma combinaçáo de reaçóes e adaptaçōes do próprio ambiente, cuja degradação local extrapola a localidade, se torna regional e em vários casos, se torna continental e trans-marítima; os desdobramentos em termos de corrosão, de alteração dos solos, de stress da vegetação, de dizimaçáo ou contaminaçáo da vida aquática e dos rebanhos indicam uma cadeia de reaçóes e de desequilíbrio graves.

- uma pressão ambientalista, organizada culturalmente em torno do ecologismo, e que está em distintos estágios de organização no âmbito de entidades de solidariedade, de bairros e de regiōes, e que se compóe políticamente com movimentos mais amplos, com partidos e grupos políticos, e que se expressa com audiência crescente em todos os países europeus, inclusive no Leste, na América do Norte, no Japăo e em alguns outros.

- e uma pressão operária, muitas vezes pela via sindical e das confederaçóes, (como ocorre p.ex. com os Sindicatos dos Químicos do ABC, 
e dos trabalhadores do pólo de Camaçari, ou com a Central CFDT, na França), quando destacam as condiçóes de trabalho e a insalubridade em suas pautas de reivindicaçáo, e atribuem às Comissóes de Prevençáo de Acidentes o concernimento também pela poluição que "sai das Fábricas", pelos riscos que possam afetar a vizinhança.

Um dos títulos que havia pensado para este roteiro era um argumento um tanto simplório, mas quase incontestável: "Se muitos trechos do planeta estão ficando mais ácidos, no Brasil isto também está ocorrendo". Apesar da obviedade, merece um detalhamento, a fim de que os mais céticos aceitem pelo menos a possibilidade de se deduzir algo a partir da experiência alheia.

Além de termos aqui no Brasil uma parte de terrenos e uma parte da atmosfera que são naturalmente mais ácidos do que outras, funcionam aqui também muitas das atividades técnicas na agricultura, na mineraçáo, na indústria e nos transportes, que comprovadamente, produzem mais acidez. Mas isto é percebido pelas pessoas de formas muito variadas, e muitas vezes nem é percebido como tal, como um problema a ser enfrentado. Aliás, em se tratando de percepçáo individual e social dos riscos, e em geral, das alteraçóes ambientais, a situação é a mesma.

A acidez, na percepção cotidiana, está associada, por exemplo, a certas frutas, que são mais ácidas do que outras, e aos preparados destas frutas como os sucos, os vinagres e vinhos. Ou está associada às várias matérias orgânicas que apodrecem, que se tornam azedas, que têm um cheiro ácido, como ocorre com as comidas que se estragam,com as bebidas e preparados que fermentam; ou também ocorre com as emanaçôes dos mangues, com o húmus das matas.

Para os cidadãos mais instruídos, os ácidos são uma "família" de compostos químicos, incluindo os inorgânicos, quando se trata de componentes ou derivados das matérias inanimadas, das rochas e das águas, os orgânicos, quando se trata de ácidos resultantes de processos biogeoquímicos e biológicos naturais, e os chamados sintéticos quando se trata de compostos produzidos em laboratórios e indústrias.

Mas, mesmo não sendo devidamente instruídos, mesmo sem termos feito cursos de Química, de Biologia ou de Geologia, alguns dos ácidos estáo na lista dos produtos e mercadorias que consumimos, e aos quais estamos expostos: os ácidos usados nas oficinas e nas residências para "limpeza" ou para remoçáo de gorduras, crostas e bôrras, os ácidos que mancham ou que tiram as manchas das nossas roupas e dos tecidos, os ácidos que estão nas prateleiras das farmácias e nos armários dos banheiros, os ácidos das baterias dos veículos, os ácidos que temperam as comidas, como o limão ou o vinagre.... 
E não se trata apenas de uma questão de paladar ou de olfato, ou de propriedades sensoriais destes materiais, mas de uma sensibilidade comparativa que vem sendo apreendida e formalizada pelos homens, desde as primeiras civilizaçóes; trata-se, de algum tempo para cá, de uma hierarquização baseada em índices quantitativos. Assim, um biólogo, ou um químico diriam simplesmente que:

- ácido é qualquer material composto cujo índice de concentração de íons de hidrogênio $(\mathrm{H}+$ ) está abaixo de 7 , numa escala exponencial que vai de 7 a 1 ; e, por simetria:

- alcalino é qualquer material cujo índice de concentração íons hidroxila (OH-) está acima de 7, numa escala exponencial de 7 a 14.

Assim, por exemplo, a água destilada é considerada neutra, com $\mathrm{pH}$ igual a 7; o vinagre, com $\mathrm{pH}$ igual a 3 , é 10.000 vezes mais ácido; a água do mar, o fermento de cozinha, com pH entre 8 e 9, sáo 10 a 100 vezes mais alcalinos; amônia, com pH igual a 12 , é 100.000 vezes mais alcalina.

Apesar desta objetividade científica, desta possibilidade de se medir e de comparar os índices $\mathrm{pH}$ de todas as substâncias, através de mediçōes consensualmente aceitas pelos estudiosos, o fato é que as percepçōes da acidez dependem, como quase tudo, do ponto de vista de quem mexe com os materiais e de quem está exposto às suas possíveis conseqüências danosas ou benéficas.

Um agricultor, por exemplo, ao aplicar calcáreo no seu terreno de plantio, está tentando contrabalançar os efeitos da acidez com o uso de um material alcalino; por exemplo, um médico que receita hidróxido de alumínio ou de magnésio para alguém que está sofrendo de acidez estomacal, está utilizando o mesmo príncipio:

- ácido mais alcalino reagem formando sais e água; em certas proporçóes e em certas concentraçóes, podem se neutralizar reciprocamente, ou pelo menos a sua mist יia desloca o índice de $\mathrm{pH}$ mais para cima ou mais para baixo. O que parace complicado, e que de fato depende de um conhecimento técnico preciso para ser compreendido, é também a experiência cotidiana de pessoas que operam as estaçóes de tratamento de águas, que mantêm as piscinas, que revelam filmes fotográficos, que fabricam doces de frutas, que respiram ou tocam materiais ácidos em seus postos de trabalho.

Em outros casos, a acidez é relacionada com a dita ferrugem, com a corrosão, pois os ácidos atacam as superficíes metálicas, os revestimentos, as pinturas, as partes submersas em água ou em contato com a água, embora a corrosão possa ser explicada também pela simples oxidaçáo em contato com o ar, ou pela açáo da maresia e da bruma mari- 
nha. A acidez é milenarmente atribuída aos fenômenos naturais, ou telúricos, como ocorre nos dias de tempestades, quando o ar fica mais ácido com as descargas dos raios, como ocorre durante e após as erupções dos vulcōes que vomitam bastante enxôfre, ou como ocorre nas épocas de maior fermentaçáo dos fundos dos pântanos e das lagunas e mangues.

Em resumo, temos que formular algumas definiçōes e argumentaçóes que representem a convergência destes variados pontos de vista, que incorporem a experiência passada $\mathrm{e}$ as constataçôes atuais:

- há regióes e zonas do planeta que são mais suscetíveis, trechos que são "normalmente" mais ácidos, trechos onde as emanaçóes ácidas săo mais freqüentes e trechos onde os efeitos da acidificação são mais imediatos ou mais marcantes;

- há processos orgânicos, geoquímicos e bioquímicos naturais, que produzem mais acidez ou que concentram mais os compostos ácidos ou acidificáveis;

- há processos técnicos, de laboratório ou industriais que produzem ou que se utilizam de ácidos, ou que emitem ácidos ou compostos acidificantes nos seus coquetéis de emissóes e de dejetos;

- e há combinaçóes técnicas e territoriais inéditas entre processos distintos que provocam ou que favorecem a acidez, e durante os quais a acidez se combina com outras alteraçóes ambientais.

Sáo estes os mecanismos e as situaçóes históricas e geográficas que este texto pretende apresentar; as informaçóes aqui coligidas são preliminares, e foram obtidas de fontes secundárias publicadas aqui e em outros países e, às vezes, obtidas de referências e observaçóes "in loco". a idéia central, e que finalmente foi para o título do texto - a pressão ambiental aponta para a via da reforma energética - pode parecer inusitada ou prematura, $e$ as demonstraçóes podem ser criticadas por falta de uma amostragem maior vu por ausência de mediçóes e equaçóes feitas diretamente pelo pesquisador; mas, é este o desafio deste texto.

\section{A Opção Energético-Intensiva Leva}

\section{à Alteração Biogeoquímica}

A acidificaçáo pode ser caracterizada como um processo múltiplo e cumulativo de degradaçáo ambiental, provocado em primeiro lugar pela emissão de poluentes ácidos ou de poluentes que sejam acidificantes após reaçóes químicas na atmosfera (ou no solo, nas águas e nos organismos vivos). Atualmente, esta emissáo supera em intensidade e amplia 
espacialmente as emanaçōes ou reaçōes químicas naturais que também sáo acidificantes.

Antes de entrarmos na descriçáo de como isto está ocorrendo no Brasil, é necessário que se estabeleça uma argumentaçăo geral, que englobe todas as manifestaçóes técnicas da acidificação no planeta, é necessário especificar como a acidificação atual é uma decorrência intrínseca de determinados processos produtivos e de determinados modos de consumo.Resumidamente, prupomos o seguinte:

- o processo histórico do desenvolvimento capitalista, desde a fase inicial do mercantilismo, mas principalmente no último século, significou também um movimento de concentraçáo populacional em aglomeraçóes urbanas e um movimento combinado de expansão geoeconômica e populacional, com grandes deslocamentos de populaçóes humanas e incorporando regiōes antes desabitadas ou habitadas por povos nativos;

- ao mesmo tempo em que se aprofundou e se disseminou a exploração dos recursos vegetais, animais, minerais e hidráulicos, multiplicaram-se os efeitos dos riscos telúricos naturais, e aumentou bastante o grau de risco sanitário-epidemiológico nas cidades e nas áreas densamente povoadas.

O motor deste processo histórico do capitalismo tem sido a acumulaçáo de capital a partir da exploraçáo do trabalho assalariado, e esta acumulaçáo vem significando d intensificaçáo da proporçáo de máquinas e instalaçôes fixas, e do uso de energia das fontes naturais, em relação à proporção de trabalho humano vivo. Para tanto, o poder econômico e político baseado nesta acumulaçáo privada de capital tenta manter prioridades tais como:

- prioridade da valorização das mercadorias sobre as condiçōes de trabalho e as condiçóes de vida da grande maioria;

- prioridade da apropriaçáo destrutiva da natureza e da exploraçáo intensiva do trabalho humano sobre a segurança $e$ a integridade individuais e coletivas.

Assim, o aumento do risco e da degradação deve ser visto como uma característica estrutural do regime capitalista contemporâneo; $e$, ao mesmo tempo, o risco e a degradação são também decorrências do uso de certas tecnologias nos países onde este regime foi historicamente limitado ou derrotado.

Neste contexto mais amplo, vejamos como se dão, em linhas gerais, a produçăo e o consumo de energéticos:

1) os empreendimentos săo privados, estatais ou mistos, de grande porte e bastante centralizados. 
2) a sustentação dos empreendimentos se baseia numa divisão técnica e hierárquica do saber, a qual, apesar das evidências e das promessas do avanço do conhecimento científico, restringe e dificulta a compreensão dos processos técnicos e das alteraçóes que eles provocam na dinâmica ambiental e na saúde humana.

3) e se isto ocorre no âmbito das empresas, temos também, em todo o conjunto da sociedade, uma centralização do poder político,que é exercido pelas alianças entre os conglomerados empresariais, os oligopólios financeiro-industriais e alguns aparelhos do Estado.

Para manter e aperfeiçoar o seu comando social e político, estas alianças vão retardando ou neutralizando as possibilidades de controle dos investimentos e da produçăo por parte dos próprios assalariados, por parte das populaçóes próximas, dos usuários, e por parte dos cidadáos em geral .

Retomando então a nossa argumentação principal: se quisermos avaliar o que ocorre no Brasil, ou em outro país capitalista, temos que nos fundamentar numa interpretaçăo histórica como esta que resumimos antes; c, em seguida, considerar a quantas anda o próprio conhecimento científico e profissional a respeito dos processos de degradação ambiental, e em particular, a respeito do processo de acidificaçáo.E o que discutiremos com mais detalhe a seguir.

\section{Poucas Certezas Científicas: A Alteração Biogeoquímica Provocada pela Queima e a Mudança no Patamar dos Riscos}

A ciência atual, apesar de toda a sofisticaçáo e de todo o aparato em uso, pode ter poucas certezas a respeito das repercussóes de sua própria aplicaçáo à produção de mercadorias; esta auto-avaliação fica ainda mais difícil quando a mesma ciência se aplica também no aperfeiçoamento da dominação social.

Sabe-se, é claro, que a dinâmica natural está bastante alterada em várias regiōes do mundo, e que há sintomas e alarmes indicando prováveis alteraçōes da dinâmica planetária. Se abandonarmos a ilusão precedente de que é sempre possível e sempre benéfico o "domínio do homem sobre a natureza", podemos entáo avaliar com maior dose de realismo, e tambem de preocupaçáo, o fato de que estas dinâmicas regionais e planetária estão sendo postas à prova em sua capacidade de sustentaçăo, e nos seus limites de diluiçáo. Podemos entáo reconhecer que se estão desafiando as possibilidades de recuperaçáo $e$ as alternativas de re-equilíbrio destas dinâmicas naturais já alteradas e em fase de alteração. 
Uma destas poucas certezas científicas é de que a produçáo e o consumo de combustíveis em grande escala, por meio das modalidades técnicas em vigor, desencadeia algumas das principais alterações biogeoquímicas que estáo em curso: aumento da concentraçáo dos gases carbônico e metano, diminuição das camadas protetoras das radiaçóes solares, acidificação. Poderáo estas alteraçóes significar a degradação final ou a morte das regióes, ou mesmo do planeta?

Depende. e, para começar, depende de como se concebe a vida no planeta, de como se concebe o único planeta com vida neste sistema solar.

Se supusermos que as eras e os processos geológicos se sucedem lentamente (comparando com o tempo da vida humana) e que a sua evoluçáo inexorável se dá com pouca ou nenhuma interferência da população humana e das suas intervençóes técnicas:

- neste caso, poderia haver a conviç̧ão de que, afinal, a humanidade neste mundo será eterna, poderia se cultivar a esperança de que, afinal, o planeta não vai piorar tanto, e talvez até melhore...

Preferimos supor, como fazem dentre outros os pesquisadores Barry Commoner, Enzo Tiezzi, Ter-Stepanian, que: ra grandeza;

- a ação humana tecnificada é hoje um agente geológico de primei-

- é a vida que regula o planeta que permite a vida.

Com isto, abandona-se a ilusão de que o domínio do homem sobre a natureza, da forma como vem sendo praticado há poucos séculos, possa se ampliar pára todos os povos, em todos os locais e indefinidamente. Particularmente no caso de queima de combústiveis fósseis e no caso de alguns processos químicos e metalúrgicos, que estáo na origem da acidificação, a idéia de "domínio" deve ser substituída pelas idéias de " risco crescente" e de "degradação violenta ou até irreversível".

Numa retrospectiva mais longa na história do homem,não podemos abstrair o fato de que "sempre" se trabalhou com o fogo e com a combustão. Mas desde que se passou a ganhar dinheiro com a produção de mercadorias energéticas, obtidas pelo trabalho humano, a tendência é que todos os compostos de carbono, ou seja,todo o mundo orgânico vivo, em decomposição e fossilizado, se tornem potencialmente combustível e fonte de lucros.

\section{a) O que Significa de fato Queimar?}

Significa desencadear reaçóes poderosas, muitas delas irreversíveis; significa basicamente oxidar o carbono e alguns outros elementos (inor- 
gânicos e metálicos), consumindo o ar, portanto consumindo o oxigênio e o nitrogênio do ar.

Queimar não é somente esquentar muito, mas esquentar rapidamente, mudar pressóes e densidades dos materiais, modificar combinaçóes químicas e moleculares, mantendo-se entretanto a soma total de massa e energia constante, conforme os princípios da termodinâmica. Os estudiosos das ciências naturais consideram a queima como uma reintroduçáo dos elementos, de seus íons e compostos nos ciclos bioquímicos prevalecentes, uma reintrodução de origem antropogênica.

A queima lança no ar e deixa no chão, nos locais da queima e nas instalaçōes onde se deu a queima, três tipos principais de substâncias e de compostos:

1) os hidrocarbonetos - $\mathrm{CxHy}$-,inclusive os aromáticos e os policíclicos aromáticos (P.C.A.), os óxidos $(\mathrm{CO}, \mathrm{CO} 2)$ e os fotos oxidantes, como o peroxi-acetil-nitrato (P.A.N.).

2) os elementos inorgânicos, (Enxofre - S -, o Nitrogênio -N -, o Potássio - K -, o Flúor - F - dentre outros) mais os seus compostos oxidados ( $\mathrm{SO}$, $\mathrm{NO}, \mathrm{NO}$, p.ex.)ou combinados com hidrogênio (p.ex.HF.HNO3) ou com metais (nitratos, sulfatos).

3) pequenas proporçóes de metais pesados, ou de íons, sais e óxidos destes metais (p.ex.Al, as, $\mathrm{Cu}, \mathrm{Hg}, \mathrm{Pb}, \mathrm{Cd}, \mathrm{Cr}, \mathrm{Sb}$ ).

Estas substâncias e compostos provêm da queima dos numerosos materiais há muito tempo queimados pelos homens: lenha, carvão vegetal, turfa; óleos e tortas obtidos das carnes e vísceras animais, das sementes e dos grãos; bagaços, palhas, cascas e fibras dos gêneros alimentícios beneficiados ou processados.

Mas os atuais coquetéis poluentes provêm principalmente da queima de carvão de pedra, (antracita, hulha, linhita), dos óleos minerais e dos gases do subsolo, e provêm da queima de qualquer um dos seus derivados, inclusive das sucatas e resíduos destes produtos (p.ex. queima dos restos de plásticos e borrachas).

\section{b) E o que Resulta da Queima?}

O resultado imediato de cada queima é portanto a produção de outros compostos, gases, misturas de gases, vapores, líquidos e partículas em suspensão, cinzas, borras. Mas o resultado acumulado de todas as queimas é uma enorme desproporçáo entre as quantidades $e$ as concentraçōes hoje emitidas - $\mathrm{e}$ aquelas quantidades e concentraçóes estimadas para a nossa era geológica, até um ou poucos séculos atrás. Isto 
ACIDIFICACÁO NO BRASIL

PRINCIPAIS FOCOS DE EMISSÃO DE DIÓXIDO DE ENXÔFRE E DE COMPOSTOS ACIDIFICANTES

PETRÓLEO
A Refinaria Grande
Refinaria Média
A Refinaria Pequena
- Petroquímica
- Central Termo-elétrica

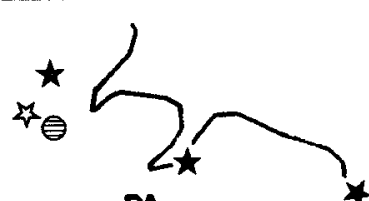

CARVÁO MINERAL
Extraç̧o e Beneficiamento
$\square$ Central Termo-elétrica
Q Carboquímica
(1) Siderúrgica

\section{BIOMASSA}

Destilarias de Álcool

$\theta$ Celulose

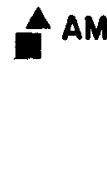

\section{$A M$}

PA

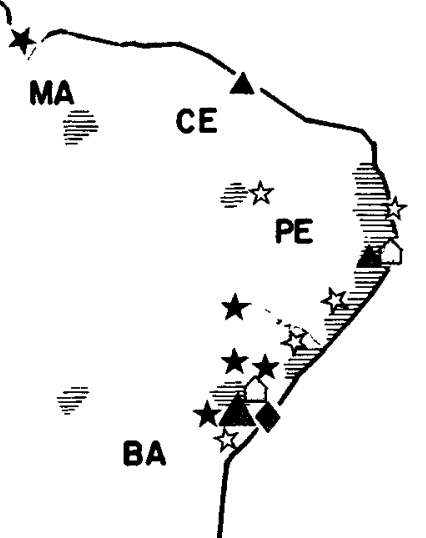

MINERACÄO E METALURGIA
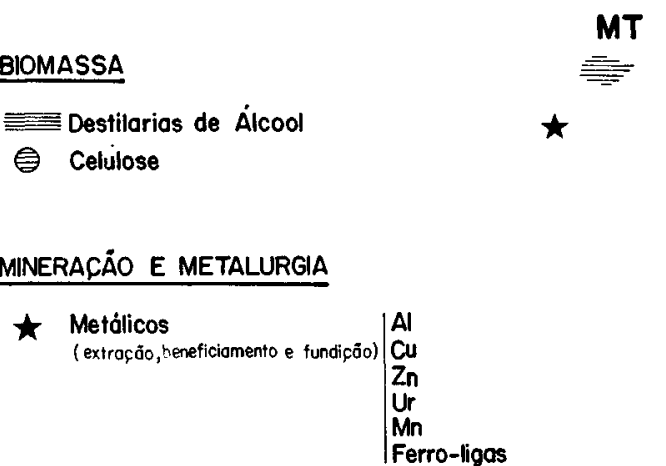

5 Nỏo Metálicos (extraç̧óo e fabricaçăo) $\mid \begin{aligned} & \text { calcáreo } \\ & \text { sal } \\ & \text { fosfatos }\end{aligned}$

RS

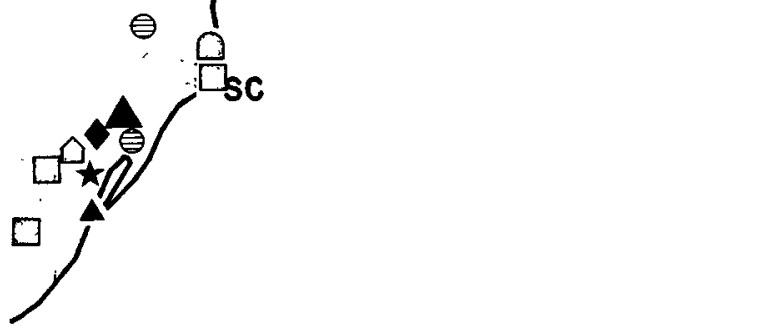

EMISSÃO DE DIÓXIDO DE ENXŌFRE EM TONELADAS ANUAIS

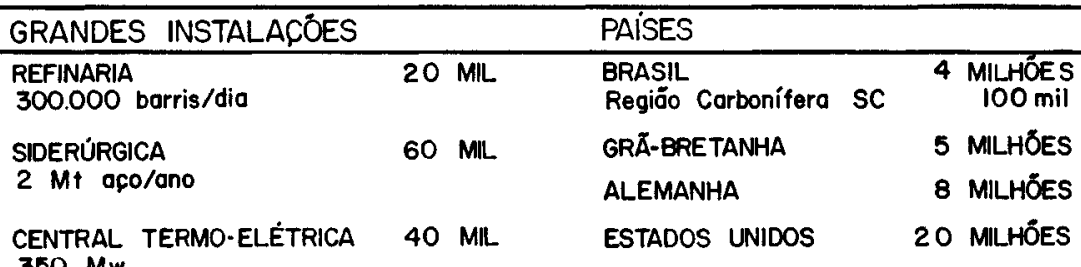


Cubatĩo: foco regional de acidificafão

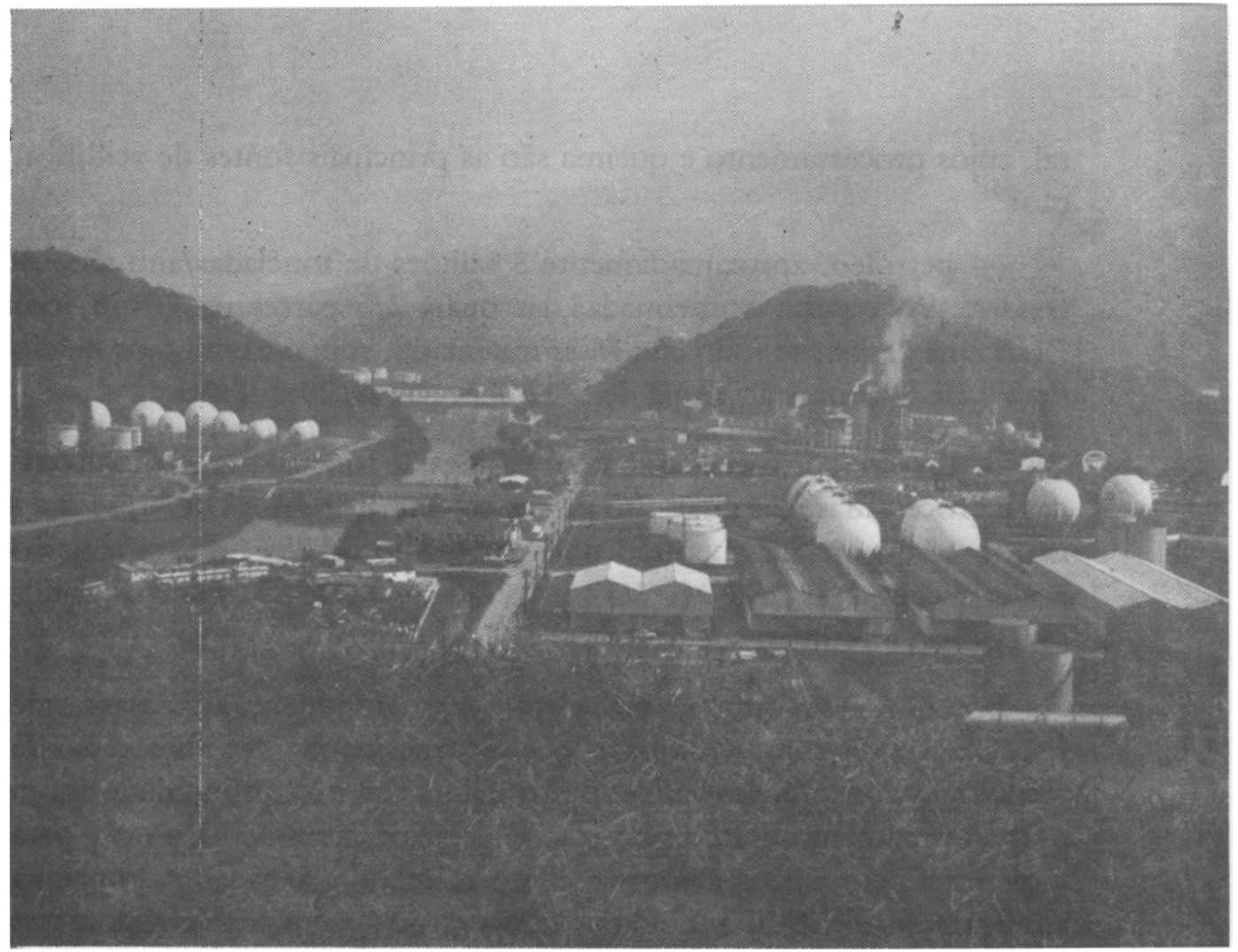

vale para o $\mathrm{CO}$, para o $\mathrm{CO} 2$, para os $\mathrm{CxHy}$ (destacando-se o metano e o benzeno), vale para os SOx e NOx, para a grande maioria dos compostos inorgânicos e para alguns dos compostos foto-oxidantes; esta desproporção é um verdadeiro salto qualitativo inédito.

A mudança de patamar pode ser demonstrada qualitativamente, como faz Ter-Stepanian, declarando já iniciada a era pós-quaternária ou era tecnogênica; e pode também ser aferida por meio dos grandes números, de que os cientistas se utilizam e que as redes institucionais e de comunicação divulgam para o público:

- a concentração de $\mathrm{CO} 2$, que estava abaixo de 280 partes por milhão na era pré-industrial, chega a $330 \mathrm{ppm}$ na metade do século XX e já deve ter ultrapassado os $350 \mathrm{ppm}$;

- a emissão total de dióxido de enxôfre por meios técnicos passou de 50/60 milhóes de toneladas por ano na primeira metade deste século para a faixa de 150/160 Mt SO2/y atualmente;

- áreas geográficas saturadas após decadas e até séculos de deposição de $\mathrm{SO} 2$, hoje estão hoje recebendo 10,20 ou mais toneladas por $\mathrm{km}$ quadrado por ano, e estão sujeitas a chuvas ácidas e a smogs fotoquímicos, com índices de $\mathrm{pH}$ abaixo de 5,0 e até abaixo de 4,0, quando o patamar histórico das chuvas estava provavelmente entre 6.5 e 5.5 .

A mesma mudança de patamar pode também ser verificada por meio das estimativas globais de consumo de petróleo e de carvão mine- 
ral, cujos processamento e queima são as principais fontes de acidificaçăo:

- petróleo: aproximadamente 3 bilhóes de toneladas/ano são extraídas, processadas e queimadas, das quais $2 / 5$ partes na URSS, nos EUA e na China; se tudo isto fosse queimado, supondo um teor médio de $2 \%$ de S, a emissáo anual de SO2 chegaria a 120 milhöes $t$.

- carvão: aproximadamente 3 bilhóes de toneladas/ano são extraídas e processadas, das quais $2 / 3$ partes na China, EUA e URSS; se tudo isto fosse queimado, supondo um teor médio de $3 \%$ de $\mathrm{S}$, a emissão poderia chegar às $180 \mathrm{Mt} \mathrm{SO2/y}$ (ref. Kohler, 1985. Para os dados agregados; a estimativa é nossa).

E, mesmo esta outra certeza cientifica, a da mudança do patamar de riscos, pode ser contestada pelos que sáo mais confiantes no sucesso da tecnologia e por aqueles mais comprometidos com a continuidade e com o aperfeiçoamento desta imposiçáo enérgetico-intensiva. De fato, para estes interlocutores, o chamado efeito estufa ainda não mostrou uma elevação sensível e duradoura das temperaturas, nem o nível dos mares subiu ainda... de fato, a acidificaçáo afinal só está comprovada em alguns pontos da Europa e da America do Norte... além disto, a tecnologia e a vontade política tudo podem solucionar...

A este propósito, é oportuno recomendar o ensaio de Remi Barré, "Les pluies acides en Europe - Un avenir ecologique en forme de scenários geopolitiques et scientifiques", onde ele registra os esforços e os desencontros entre os governos e as forças sociais dos vários países para conter a emissảo de SO2 e dos NOx; ele aponta, a mesmo tempo:

- uma grande oportunidade política para estas sociedades se entenderem sobre uma alteração irreversível e sobre os prejuízos crecentes em seus próprios territórios e nos territórios vizinhos ou distantes; ou

- uma via de declínio econômico e político, de piora lenta mas inexorável das condiçóes de vida, se a primeira oportunidade náo for aproveitada.

A questão da acidificação, lá onde o processo vai sendo comprovado, deixou de ser apenas uma reclamaçáo de alguns setores da populaçáo, extrapolou a bandeira do ecologismo nórdico, abriu uma importante controvérsia científica, e está se tornando um campo de pressóes sociais, internamente aos países, e de pressóes político-estratégicas, nas relaçóes entre países vizinhos próximos e mesmo entre países distantes.

Agora podemos lançar mão destas duas certezas científicas - a alteraçáo biogeoquímica já desencadeada, e a mudança do patamar de riscos - para iniciar a nossa avaliaçáo sobre o processo de acidificaçáo que está certamente em curso no Brasil. 


\section{No Brasil, Causa e Efeito Esclarecem ou Escondem a Responsabilidade?}

Para encaminhar o debate sobre a acidificação no Brasil, já tomamos uma primeira precauçáo, que foi explicitar os mecanismos gerais que associam o risco e a degradaçáo a determinados processos produtivos e a certas modalidades técnicas. Porém, a sequência de nossa argumentação daqui em diante irá frequentemente esbarrar em limitaçōes intelectuais e políticas presentes em nossa "cultura desenvolvimentista" tão peculiar.

Uma limitaçáo é a idéia tão repetida de que são somente os países mais ricos que provocam a poluiçáo; um argumento comum que se segue a esta idéia é o de o nosso problema é primeiramente chegar a produzir tanto quanto eles, e depois entáo ir adaptando e regulamentando a nossa indústria para evitar os erros dos europeus e dos norteamericanos.

Esta argumentação se assemelha a uma ideologia: destina-se a realçar o senso comum ( de fato, o acúmulo de poluiçáo nas regióes mais industrializadas é impressionante) e a escamotear alguma consequência ou implicaçáo grave (se adotarmos as mesmas tecnologias e ampliarmos a indústria local, sofreremos riscos e prejuízos comparáveis aos deles).

Ora, as instalações que queimam óleo e carvão mineral aqui no Brasil, as que beneficiam e fundem metais e ligas, as que produzem celulose, cimento, fertilizantes, têm escalas de produçáo, potências, vazões, parâmetros de fabricação e de emissão de dejetos comparáveis às instalaçōes similares no exterior. $\mathrm{E}$ mais: apesar das várias distinções técnicas e organizacionais que certamente existem, a aparelhagem básica, as receitas industriais e os tipos de materiais processados sáo os mesmos ou semelhantes aqui e no exterior.

Não estamos com isto dizendo que a indústria aqui é igual à de lá; apenas insistimos no fato de que, nestes setores aqui comentados, $o$ parque técnico instalado no Brasil é de primeira grandeza em termos internacionais. Mas há nuances, e elas devem ser citadas: algumas destas instalações aqui têm menos tempo de funcionamento do que as européias ou norte-americanas, o que é um trunfo relativo, pois, em geral, quanto mais velhas, sáo mais arriscadas e mais poluidoras.Porém, há também agravantes, pois as competências técnicas e profissionais mobilizadas para a operação e a manutenção destas instalações são aqui mais baixas, e, pior, o quanto se despende aqui com medidas e com atividades preventivas e de segurança é muito menos do que o que se despende lá, o que é um handicap negativo, pois as depreciaçóes serão mais rápidas e as panes técnicas mais prováveis.

De toda forma, as verdadeiras dimensóes do problema, a amplitude 
e os ritmos destes mecanismos não são conhecidos no Brasil, nem por mim, nem por nenhum outro estudioso isoladamente, e talvez náo o sejam nem pelos institutos de pesquisa, universidades ou agências governamentais. Quando alguns mecanismos ou alguns efeitos são investigados e os seus resultados são divulgados, coloca-se a questão da validade das explicaçóes e das mensuraçóes efetuadas.E aí, a controvérsia vai se instalar, de duas maneiras:

1) Deve-se restringir as explicaçóes somente para a poluiçăo atmosférica de tal regiáo em tal época? deve-se associá-la necessariamente ao funcionamento de determinadas modalidades técnicas ali existentes?

Num certo sentido, tais perguntas se justificam, pois cada combinaçáo entre modalidades técnicas/populaçōes humanas concernidas/dinâmicas naturais local e regional é uma combinaçáo única. Todavia, destacar a singularidade de cada degradaçăo poderia bloquear 0 avanço da investigaçăo: nada se poderia afirmar a respeito das situaçóes onde não se mediu nada, ou onde se mediram apenas tais variáveis em tais condiçóes. No limite, esta atitude levaria à negação da própria especulaçáo científica, à negação da possibilidade de deduçáo e de avaliaçáo comparativa, pois... o "fenômeno" só existiria quando devidamente registrado e mensurado.

2) Deve-se levar em conta os sintomas observáveis e mensuráveis como indicadores da existência do processo de degradação? $\mathrm{Ou}$, ao contrário, deve-se considerar a acidificaçáo como certeira e inevitável a partir da simples existência das modalidades técnicas que a provocam?

Bem, se nos mantivermos no quadro teórico em que nos formamos como profissionais e como pesquisadores, teríamos apenas uma trajetória válida para os raciocínios:

- a busca de um mecanismo lógico que relacione causas e efeitos, com a definiçăo de variáveis e de dimensóes físicas que permitam elaborar parâmetros téoricos ou experimentais, os quais por sua vez, seriam aceitos como critérios para dimensionar, projetar e pôr em funcionamento os sistemas técnicos.

Entretanto, o avanço da degradação e do risco é cada vez mais observável, e mais do que isto, seus prejuízos e suas ameaças são vivenciados pelas pessoas de tal forma que o drama não pode simplesmente ser apagado da memória dos indivíduos e dos grupos humanos. Quando os tais "custos do progresso" váo se tornando mais claros, maiores, mais frequentes, a tendência é que aquela trajetória, tão cara aos engenheiros e aos aplicadores da ciência à produçáo, seja colocada sob suspeita, ou desconfiança; nos estágios mais complicados do problema, esta mesma lógica cartesiana passa a ser rejeitada ou combatida por alguns setores sociais. 
Além disto, na compreensão do processo de acidificação, muita coisa depende da visibilidade espacial e da percepçáo temporal que uns e outros têm a respeito da mesma situação; e muita coisa depende da possibilidade de se deduzir (a partir das situaçóes mais conhecidas) explicaçóes válidas, ou pelo menos pistas frutíferas para a investigação das situaçōes menos conhecidas. Já vimos, com os relatos dos pescadores, dos fazendeiros e dos guardas florestais, que o conhecimento popular e profissional é uma fonte fundamental para a ciência.

O problema contudo náo é meramente técnico, nem se explica apenas por argumentos lógicos cientificamente aceitos, pois estamos no campo das relações sociais. Se a produção de mercadorias, se a apropriaçáo dos espaços e das formas de vida se dão cada vez mais sob o comando empresarial e/ou estatal, é bastante plausível atribuir a estas esferas institucionais e a estes grupos dirigentes a responsabilidade pela opção energético-intensiva e portanto, pelo desencadeamento das causas da acidificação, e também da concentração de gás carbônico e de outros de riscos tecnológicos.

Além disto, sabendo que os efeitos da acidificação são variados, combinados, que alteram as condiçôes estruturais dos solos, das águas, da cobertura vegetal, prejudicando a saúde e a integridade dos homens e de todos os seres vivos, seria também plausível que definíssemos a população em geral, não somente a atual, mas as geraçóes sucessivas, o seu patrimônio comum, a sua base territorial, como aqueles que suportam os prejuízos da acidificaçáo e dos demais processos de degradação.

Neste ponto, algo crucial vem à tona e passa a dominar a cena: a chamada verdade científica pode ou não, qualificar as relações sociais? $O$ veredito técnico pode ou não se tornar também um veredito jurídico?

Recapitulemos novamente: a relaçáo entre a atividade técnica da produção mercantil, com as suas formas organizacionais próprias e as condiçóes gerais de vida dos trabalhadores e de toda a população significou historicamente uma sucessáo de conflitos duros a respeito do acesso e do uso dos recursos físicos e biológicos do planeta, e um emaranhado de litígios em torno dos valores, das proporçóes entre os valores, em torno dos prejuízos e das responsabilidades por tais prejuízos.

Supostamente, havendo vítimas e prejudicados em decorrência de decisóes ou de omissóes das inpresas, deveria haver uma responsabilização que levasse, ao mesmo tempo, ao socorro das vítimas, ao ressarcimento dos prejuízos, e deveria haver uma reavaliaçáo que levasse à modificaçáo ou à reforma, que evitasse ou diminuísse a ocorrência de novas vítimas e novos prejuízos.

Entretanto, a responsabilidade empresarial vem sendo em boa parte mercantilizada, por meio da atribuição de valores monetários à insalu- 
bridade e à periculosidade do trabalho, e, em alguns casos, por meio da atribuiçáo de valores de indenizaçáo a serem pagos aos indivíduos ou aos próprios poderes públicos. Esta mesma responsabilidade vem sendo transferida das emprêsas para estes mesmos poderes públicos, supostamente aptos a tratar da insalubridade e dos riscos dentro e fora dos estabelecimentos, supostamente preparados para tratar dos padróes de qualidade do ambiente alterado pelo funcionamento destes estabelecimentos, e para tratar das situaçóes mais críticas.

Em muitos casos graves e cada vez mais frequentes, os prejuízos e os crimes afetaram trabalhadores, usuários, vizinhos, consumidores, individualmente, em pequenos grupos e em coletividades inteiras e numerosas, e as causas não foram esclarecidas ou não foram tornadas públicas. O que se viu e o que se verá ainda por algum tempo, é a escamoteação, a invenção dos bodes expiatórios e, em certos casos, a própria fraude; náo faltam explicaçóes do tipo: a culpa é do piloto, do operador, do maquinista... não há como responsabilizar a direçáo empresarial... não há como puní-la ou como obrigá-la a fazer reparaçóes e reformas necessárias...

Ainda assim, os acidentes graves, os traumatismos coletivos de maior repercussão são melhor esclarecidos do que os processos lentos ou latentes de degradaçáo, como é a acidificaçáo. Por exemplo, em alguns estados brasileiros, os organismos de controle da poluiçăo ambiental (p.ex.Cetesb, em SP; Feema; RJ; Fatma, SC; Copam, MG) pretendem regulamentar as emissóes de $\mathrm{SO} 2$ por meio de valores máximos da concentração do dióxido na atmosfera, nas imediaçóes das chaminés e em círculos de alguns quilômetros em torno; estes organismos especificam as taxas máximas de $\mathbf{8 0}$ microgramas por metro cúbico como média anual, e de $300 \mathrm{ug} / \mathrm{m} 3$ como média díaria,decretando que estes sáo os valores suportáveis, quando já se sabe que nas regiōes mais castigadas da Europa o depósito anual médio de $S O 2$ está na faixa de $20 / 30 \mathrm{ug} / \mathrm{m} 3$.

Ora, é melhor do que nada, pode-se replicar. Mas pode ser até pior, conforme o ponto de vista: com este método burocrático que se reveste de aparência científica, ignora-se que as chaminés emitem coquetéis poluentes e que estes coquetéis reagem quimicamente na atmosfera. A aparência científica, por meio do uso de designaçóes técnicas e de unidades de medida, pode desabar quando entramos mais no mérito do problema.

Com um método que prioriza as medidas de concentraçōes do gás SO2 ou dos NOx na atmosfera ou no rés do chão próximo das chaminés, omite-se o fato elementar de que os íons ácidos $(\mathrm{H}+)$ são formados após as reaçóes do coquetel na atmosfera, com as nuvens, a umidade, e com o terreno e a vegetaçáo onde caem; despreza-se o fato hoje bastante 
conhecido de que as precitaçóes ocorrem nas imediaçóes da chaminé e em todos os percursos dos ventos e das chuvas, em distâncias às vezes muito grandes (dezenas, e até centenas de kilômetros longe dos focos emissores).

E mais: ao se priorizar as medidas de concentraçăo (ug/m3 ou ppm, p.ex.) pode-se estar atendendo às recomendaçóes de ordem médica, pois os efeitos sobre a saúde humana são mais prováveis quando se respira um ar mais densamente contaminado. Porém está se desprezando um fato crucial para a compreensão da acidificação, pois a acidez que finalmente retorna à terra é diretamente proporcional às toneladas de compostos de $\mathrm{S}$ e de $\mathrm{N}$ emitidos e náo à concentração do gás $\mathrm{SO} 2$ ou NOx.(Isto porque cada molécula do gás, após reagir na atmosfera, produz dois íons $\mathrm{H}+$, e cada molécula de $\mathrm{NO}$ ou $\mathrm{No} 2$, nas mesmas condiçóes, produz um íon $\mathrm{H}+$, e todos os íons caem)

$$
* * *
$$

Estes comentários bastam, a nosso ver, para que se consiga relacionar o caso brasileiro com os casos europeus e norte-americanos: é comum se ouvir por aqui que a acidificação não ocorre, que as emissóes estão abaixo dos limites admissíveis, e que năo há como comprovar científicamente que tal indústria está prejudicando tal região de tal forma.

A disposição intelectual e ética de quem diz ou escreve tais coisas é comparável às disposiçóes do governo Thatcher (quando argumenta que năo está devidamente comprovado que os coquetéis das chaminés das Ilhas Britânicas acabam precipitando na Escandinávia) ou do governo Reagan (quando argumentou anos em seguida que não estava ainda suficientemente comprovado que tais lagos ou florestas canadenses estavam sendo prejudicados pelos coquéteis das chaminés de certas regióes dos EUA), ou do governo Gonzalez, na Espanha (que resiste a seguir os critérios já aprovados pela Comunidade Econômica Européia para o controle das emissōes das termoelétricas).(v. Acid. Magazine 1984, Cruz 1989).

Estamos assim diante de um jogo ideológico e político de grandes proporçóes, mais um dos vários jogos criados pelas relaçóes entre a indústria e as coletividades humanas; a busca científica das relaçóes comprovadas e detalhadas entre causa e efeito, que tem sido essencial para estabelecer vereditos jurídicos em tantos casos, pode funcionar também como um amortecedor das pressóes sociais e diplomáticas que exigem reformas energéticas e controles ambientais.

Cremos que o desafio maior, no caso do Brasil, talvez não seja o estabelecimento da relação causa e efeito, mas, sim, a abertura das infor- 
maçōes empresariais e técnicas necessárias para que se consiga quantificar e qualificar as múltiplas dimensóes dos prejuízos. O desafio vai além, é a busca da compreensão da sinergia entre processos técnicos e processos naturais, é a busca de uma demarcação temporal e espacial suficiente para que se possa enfim, nomear as estruturas institucionais $e$ as equipes dirigentes responsáveis pelos prejuízos.

\section{Deduzindo, e, se Possível, Medindo as nossas Manchas Ácidas}

O lançamento de dióxido de enxofre é provavelmente o componente principal da acidificação da atmosfera em várias regiōes brasileiras. Um patamar mínimo de lançamento anual poderia ser obtido a partir das quantidades de petróleo e carváo queimados e processados e de seus teores de enxofre:

- mais de 60 milhóes t/y de petróleo, local e importado, com teores entre $0,1 \%$ e $5 \%$ de $S$; entre 15 e 20 milhóes t/y de carváo e coque mineral, com teores entre $1 \%$ e $8 \%$; somente estes dois componentes indicam, por meio de cálculo teórico, algo entre 2,5 e 3,5 Mt SO2/y.

Este seria um patamar mínimo, pois deve-se acrescentar os compostos de enxofre lançados pelo processamento de minérios metálicos que contêm algum teor de enxofre, e pelo processamento químico do próprio enxofre e de seus ácidos comercializados. Neste caso, poderíamos chegar à faixa das $4,0 \mathrm{Mt} / \mathrm{y}$, próxima aos valores de emissão dos principais países poluidores da Europa. $O$ fato de estarmos numa superfície muito maior do que estes países poderia parecer uma vantagem, mas, na realidade, as regióes onde estáo os focos somam uma pequena parte deste imenso território. a conclusão é que: onde ocorre acidez, o patamar pode ser o mesmo da Europa Central e das Ilhas Britânicas.

Nos oito e meio milhóes de quilômetros quadrados do território brasileiro certamente funcionam milhares de chaminés cujos coquetéis são acidificantes, e milhóes de canos de descarga de motores cujos coquetéis também são acidificantes. São as chamadas fontes estacionárias e móveis, e quase todas são devidamente cadastradas: atividades industriais, minerais, energéticas, agrícolas; automóveis, caminhōes, ônibus, tratores, motocicletas; trens, embarcações e aeronaves. Para o que nos interessa aqui, sáo todos pontos de queima de combustíveis fósseis ou pontos de emanaçóes e descargas de materiais acidificantes, que designamos como focos emissores de acidificação e de outros processos degradantes.

Comecemos por uma primeira discriminação destes focos emissores, agrupando-os conforme as modalidades técnicas empregadas e indicando suas localizaçóes, e eventualmente, suas denominaçôes: 
- muitos dos focos emissores formam verdadeiras faixas e trajetos de contaminaçáo atmosférica de baixa altitude, ao rés do chão ou quase isto, acompanhando os deslocamentos dos meios de transporte equipados com motores a combustáo interna;as estimativas apontam estes focos como responsáveis por mais de $70 \%$ da emissão dos NOx no país, por mais de $85 \%$ da emissão de CO, e mais de $65 \%$ da emissăo dos CxHy.

- os outros focos formam zonas de concentração ou de proximidade de processos produtivos que contaminam a atmosfera média e a alta, cujas chaminés e descargas respondem por mais de $90 \%$ da emissão de SO2 no país, por mais de $80 \%$ da fuligem (material particulado), por cerca de $20 \%$ dos CxHy e quase $30 \%$ dos NOx.

Os principais processos produtivos que devem ser especialmente associados à acidificaçáo no Brasil incluem, pelo menos, os seguintes:

1) as indústrias químicas e laboratórios que produzem os próprios ácidos comercializados, e mais aquelas que os empregam em grandes quantidades, ou em concentraçóes altas, ou em condiçōes propícias às emanaçóes, aos vazamentos e às reaçóes químicas com a atmosfera (p.ex.fábrica de ácidos clorídrico - HCL, ou sulfúrico - H2SO4);

2) usinas de beneficiamento e de fundição de metais e de ligas que trabalham com minérios sulfurosos (p.ex.carvão mineral piritoso, sulfatos de Cobre), ou com minérios alcalinos que sáo atacados por ácidos nos vasos de reaçáo, ou com misturas fundentes que podem liberar compostos ácidos (p.ex.criolita nas cubas de eletrólise do alumínio, liberando HF - ácido fluorídrico).

3) processamento de bicu-massa, cujos procedimentos de fermentaçăo liberam ácidos orgânicos (p.ex.na fabricaçăo do álcool), ou cujos procedimentos de clarificaçáo utilizam sulfitos ou sulfatos para neutralizar as lavagens de soda (p.ex.fabricação de pasta de celulose e de papel, que emite gás sulfídrico - H2S - ou compostos orgânicos sulfurosos, as mercaptanas).

4) caldeiras, fornos industriais, torres e reatores de processamento termoquímico que queimam ou processam carvăo mineral,petróleo e os seus derivados, destacando-se aí as instalaçóes de todo o circuito do petróleo/petroquímica, as centrais termo-elétricas, uma parte das fábricas de fertilizantes minerais e de cimento, e uma parte das usinas de processamento de alimentos e bebidas.

Quando se tem numa mesma zona geográfica alguma combinaçăo entre duas ou mais destas modalidade, estáo dadas as condiçóes para que se chame uma certa região de foco regional de acidez. e, a cada foco regional de acidez, corresponderá certamente alguma mancha ácida, ou 
seja, alguma superfície de terras e de águas que recebe preferencialmente as precipitaçóes provenientes de um ou mais de um foco emissor.

Se o parque industrial, ou mesmo única grande instalaçáo,se combina com uma área urbana de médio ou grande porte, ou se está a uma distância pequena das aglomeraçōes (p.ex.de 10 a $50 \mathrm{~km}$ ), ou se está a uma distância pequena ou média de outros focos emissores (p.ex.até 150 km.), temos aí uma situaçáo local/regional bastante comparável às áreas européias, norte americanas e canadenses uma zona de deposição alta ou máxima (p.ex. mais de 5, ou mais de 20 ton. $\mathrm{SO} 2 / \mathrm{Km} 2 / \mathrm{y}$ ).

Um primeiro rastreamento da indústria nacional pode se iniciar pelas instalaçóes de produçáo de energéticos e dos processos energético-intensivos, e apontaria já algumas dezenas de focos regionais de acidificação, e, portanto, algumas dezenas de manchas ácidas formadas a partir destes focos (esclarecemos que nesta versão parcial não foram ainda consideradas as principais indústrias químicas fabricando ácidos ou utilizando quantidades ou concentraçōes importantes de ácidos fabricados pelas primeiras; se isto fosse feito, seriam acrescentados de dez a quinze novos focos neste primeiro mapeamento, e na maioria dos casos estes focos estariam dentro ou próximos dos que estăo aqui assinalados).

\section{Grupo I - Circuito de Petroleo/Petroquímica}

Incluam-se todas as refinarias de petróleo, agrupadas p.ex. em três "famílias" : as grandes, em Paulínia e em São José dos Campos, SP; em Duque de Caxias, RJ e em Araucária, PR; as médias em Mataripe, Ba (acrescente-se a fábrica de asfalto nas proximidades e a Carbono Coloidal em Candeias); em Canoas, RS; em Betim, MG; em Cubatáo, SP (acrescente-se a fábrica de coque metalúrgico); e as pequenas, em Rio Grande, RS; Capuava, SP; em Manguinhos, Rio de Janeiro. Incluam-se também a fábrica de asfalto de Fortaleza, a fábrica de borracha sintética no Cabo, PE e o processamento do xisto betuminoso em São Mateus do Sul, PR; e acrescentem-se os parques petroquímicos principais em $\mathrm{Ca}$ maçari, BA, em Paulínia, SP, em Capuava, SP, em Triunfo, RS;acrescentem-se as centrais termo-elétricas médias e grandes queimando óleos pesados em Santa Cruz, Rio de Janeiro, em Guarapiranga, São Paulo, em Igarapé, MG, em Manaus, aM.

\section{Grupo II - Circuito do Carvão Mineral}

Incluam-se as duas principais áreas de mineração e beneficiamento no Sul de Santa Catarina (Crisciúma e municípios vizinhos) e no sul do 
Rio Grande do Sul (Bagé), onde também foram instaladas e estão sendo ampliadas centrais termo-elétricas de médio e grande porte queimando carvão. Acrescente-se, em Imbituba, SC a indústria carboquímica; incluam-se os principais pontos de queima de carvão e coque metalúrgico de origem brasileira e estrangeira, ou seja: as siderúrgicas de grande porte em Cubatáo, SP; em Sepetiba, e em Volta Redonda e Barra Mansa, RI; em Monlevade, Sabará, Ipatinga e Timóteo, MG; em Tubarão e Vitória, ES; em Aratu, BA, e na área metropolitana do Recife, PE.

\section{Grupo III - Circuito da Bio-Massa}

Destacamos, por enquanto, as zonas de maior concentraçáo geográfica das destilarias de álcool, nos vales dos rios Piracicaba e Mogi-Guaçu, em SP, no norte fluminense, no Recôncavo baiano e nas terras baixas do Nordeste Oriental, passando por Sergipe, Alagoas, Pernambuco, $\mathrm{Pa}$ raíba e Rio Grande do Norte. Incluam-se pelo menos as maiores fábricas de celulose e papel no vale do Rio Doce: Cenibra e Santa Terezinha próximas de Governador Valadares, MG e Aracruz, próxima de Linhares, ES; Champion, em Mogi-Mirim, Ripasa, em Limeira, SP; em Suzano e Jacareí, também em SP; Klabin em Telêmaco Borba, PR e próximo a Lages, SC; a Riocell, defronte a Porto Alegre, RS; a Jari, fronteira PA/AP.

\section{Grupo IV - Circuito da Mineração/Metalúrgica}

Além das siderúrgicas grandes já citadas, incluam-se as instalaçōes de beneficiamento e fundição de alumínio em Sorocaba, SP; Poços de Caldas e Ouro Preto, MG; em Santa Cruz, Rio de Janeiro; em Aratu, BA; na ilha de São Luiz, MA e em Barcarena, próximo e Belém PA; as de cobre em Camaquá, RS, em Jaguarari e em Camaçari, BA e as de zinco (em Vazante, em Três Marias, e próximo de Além Paraíba, MG). Acrecente-se a mineraçáo e beneficiamento do urânio próximo a Poços de Caldas, MG, e também algumas instalaçóes importantes de ferro-ligas, como as de Várzea da Palma, Pirapora e Montes Claros, MG, a de Pojuca, BA, a de Tucuruí, PA, dentre outras.

A relaçáo é naturalmente incompleta e sujeita a críticas e reparos, mas serve de base para iniciar uma delimitaçáo das manchas ácidas no Brasil;vale dizer que o detalhamento $e o$ aperfeiçoamento deste mapeamento somente seriam possíveis no quadro de uma equipe de pesquisa multiprofissional, dedicada durante um bom tempo a abrir novas fontes de informação e a cruzar os dados técnicos e geográficos em função desta meta. 
Se pretendermos passar deste mapeamento indicativo dos focos de emissáo alta para um mapeamento indicativo das áreas geográficas atingidas pelo processo de acidificaçáo, teremos muitas dificuldades teóricas e empíricas. Por enquanto, comentaremos apenas alguns dos principais mecanismos e algumas das possibilidades que consideramos as mais prováveis.

A intensidade da acidificação em curso depende primeiramente dos tipos de combustíveis e de minérios processados, e, mais diretamente, depende dos teores de enxôfre destes materiais e da forma como são queimados e ou processados.

Já os efeitos difusos e cumulativos da acidificação dependerão de numerosos fatores e circunstâncias locais e regionais, de ordem técnica ou relativos à dinâmica natural, e dependerão de processos históricos diferenciados. Se nos restringirmos aqui às modalidades técnicas citadas, e às fontes estacionárias de médio e grande porte, podemos seguir as seguintes pistas:

a) as chaminés que emitem estes coquetéis têm características de projeto que pré-determinam, em parte, as dimensóes dos prejuízos: a composiçáo dos coquetéis poluentes, ou a proporção de gases, vapores, gotículas e partículas; a vazão, a velocidade e a temperatura de saída destes coquetéis.

b) o caminho aéreo de um coquetel poluente dependerá particularmente da altura da chaminé, de sua posiçáo relativa no relevo local e regional, e das direçóes e altitudes das massas atmosféricas que aí se deslocam.

c) a dinâmica meteorológica e as reaçóes químicas na atmosfera são bastante variadas no tempo e no espaço, e na acidificação parecem influir muito as variaçóes de umidade e os ventos locais; $e$, um dos fatores-chaves é a relaçăo entre as cotas da base e do topo da chaminé e a sua posiçáo na geomorfologia local/regional.

d) as precipitações íons $\mathrm{H}+$ (e dos óxidos e ácidos que podem formá-los posteriormente) cairáo evidentemente a jusante dos ventos e das chuvas, mas, o formato e a superfície das áreas de precipitação variam, para o mesmo foco emissor, durante o dia e durante $o$ ano.

e) os efeitos são também bastante distintos se estes terrenos se estendem numa planície, num planalto ou num relevo ondulado com poucas diferenças de cotas, ou se o caminho dos ventos e chuvas estiver afunilado por uma garganta de serra, ou se houver uma chapada, uma falésia, ou uma crista montanhosa que funcione como barreira orográfica, em cujas vertentes seráo recolhidas muitas das chuvas provenientes dos focos de acidificação. 
Estes seriam os passos mínimos para que se possa deduzir e equacionar o que se passa nas manchas ácidas brasileiras. É claro que são feitas medidas que direta ou indiretamente comprovariam a existência destas manchas $\mathrm{e}$ as condiçôes atuais de degradação, mas são muito poucas mediçóes. Por isto caberia, numa proposta de investigação mais ampla e duradoura, cruzar as informaçóes provenientes de pesquisas acadêmicas com dados dos centros de meteorologia e das empresas de águas, com as mediçóes e foto-interpretaçóes provenientes p.ex. do INPE Instituto Nacional de Pesquisas Espaciais, do NMA - Nucleo de Monitoramento Ambiental da Embrapa, da Cetesb, da Feema e órgáos similiares. Por enquanto, avançaremos alguns indicadores ou números que estáo citados $\mathrm{em}$ artigos acadêmicos, $\mathrm{em}$ relatos oficiais e em matérias de jornais .

Quando a CESP - empresa estatal de eletricidade - anunciou dois novos projetos de usinas termo-elétricas em Paulínia (próximo a Campinas) e em São José dos Campos, SP, uma das reações a este anúncio previa o aumento da acidez nas chuvas das regiōes ameaçadas (ref.Sevá e Ferreira, 1989).

Posteriormente a própria empresa divulgou alguns dados do "back ground"de $\mathrm{SO} 2$ já existente na região de Paulínia: os principais focos de emissão, a refinaria da Petrobrás e o complexo químico da Rhodia, jogavam 20.000 e $10.000 \mathrm{t} \mathrm{SO2/y}$. Nas proximidades, as indústrias da cidade de Americana jogavam mais $30.000 \mathrm{t}$, e a estimativa para a região de Campinas estava na faixa das $\mathbf{8 0 . 0 0 0}$ toneladas.

Se compusermos aqui um quadrilátero de $150 \mathrm{~km}$ por $150 \mathrm{~km}$ que englobe esta região mais a Região Metropolitana de São Paulo, e as regióes de Cubatáo e de Sáo José dos Campos, poderiámos ter uma estimativa aproximada bastante alarmante:

Região Metropolitana de SP

Região de Campinas

Região de São José dos Campos

Região de Cubatáo

total aproximado

$\begin{array}{ll}\text { aprox. } & 120.000+S O 2 / \mathrm{y} \\ " & 80.000 \\ " & 50.000 \\ & 50.000 \\ & ======= \\ & 300.000 \mathrm{t} S \mathrm{SO} 2 / \mathrm{Y}\end{array}$

Esta ordem de grandeza já obrigaria a incluir esta quadrícula no grupo das zonas críticas de emissão, se seguirmos a metodologia do NIAR (Oslo), já citada. E se todo o SO2 cair na mesma quadrícula, com $22.500 \mathrm{~km} 2$, obteríamos 13,3 ton $S O 2 / \mathrm{km} / \mathrm{Y}$, o que nos faria incluir esta área entre as áreas de deposição alta (usando a metodologia da OCDe, já citada). 
Năo por acaso, medidas efetuadas na Serra da Cantareira entre 1977 e 1979 já indicavam chuvas com pH entre 6,6 e 4,15, das quais $86 \%$ das amostras podiam ser consideradas ácidas, abaixo do $\mathrm{pH}$ histórico de 5,6 (ref.Fonseca Cesar, 1986 e Tuffani, FSP, 13.04.1990).

Uma regiăo brasileira castigada pela acidez é a zona carbonífera do sul de Santa Catarina, onde as denúncias de degradação ambiental vêm junto com as tragédias dos acidentes dentro das minas $\mathbf{e}$ das doenças ocupacionais, desde mais de uma década atrás. $O$ minério ali extraído tem alta proporção de pirita (Sulfetos de Ferro), o que provoca acidez desde a fase inicial de extração e lavagem: numa amostragem de 160 pontos de mediçáo nos cursos d'agua, técnicos do DNPM encontraram mais da metade dos pontos com $\mathrm{pH}$ menor ou igual a 3,0, principalmente no interior das minas, nas minas abandonadas, nas drenagens, infiltraçóes e águas pluviais dos montes de rejeito (chamados de "poluiçáo sem dono" ) e nas saídas das águas de lavagem (ref. Cortes e Anjos, 1989).

Uma forma original de acidez também se encontra aí em Santa Catarina, pois as pilhas de material rejeitado com alto teor de pirita entram em combustão espontânea com a atmosfera e liberam grandes quantidades de $\mathrm{SO} 2$; além disto, com o funcionamento da ICC-Carboquímica em Imbituba e da Central térmica Jorge Lacerda, proximo dali, a acidez vêm também da forma clássica,pelas chaminés destas caldeiras. Em Imbituba, já há muitos anos, fêz-se um acordo pelo qual a ICC somente soltaria os gases quando o vento nảo soprasse na direção da cidade e de suas praias; na área de Crisciúma, a dificuldade de abastecimento d'agua potável é crescente, pois até os lençóis subterrâneos estáo comprometidos e há casos em que a água tem que ser trazida de longe em caminhóes-pipa...

O patamar de acidificaçáo aí é praticamente o mesmo das piores regióes européias; o pesquisador Humeres ("Ciência Hoje", março 1990), da UFSC calcula as emissóes em mais de $100.000 \mathrm{t} / \mathrm{y}$ de SO2; se tomamos a zona carbonífera com uma superficie da ordem de 10.000 $\mathrm{km} 2$, o índice seria maior do que $10 \mathrm{t} . S 02 / \mathrm{Km}^{2}$ por ano.

As condiçōes para um impasse social comparável aos das áreas carboníferas da Europa também estáo dadas: já se começa a contrapor o fantasma do desemprego $e$ do fechamento das minas às reclamaçóes crescentes e justas sobre a piora das condiçōes de vida.

Uma das regióes mais castigadas pela poluição atmosférica e onde as denúncias e litígios se avolumam é a área de Vitória, ES. Dados oficiais publicados em jornal (JB, 01/07/90)indicam, somente para as instalaçốes de beneficiamento de minério da CVRD e para a siderúrgica de Tubarão, uma emissão anual de $\mathbf{2 3 . 0 0 0}$ toneladas de SO2. 
É provável que estimativas semelhantes a estas já estejam ou venham a ser comprovadas nas demais manchas ácidas aqui indicadas; de toda forma, alguns dos sintomas estão visíveis na paisagem para quem quiser ver e, se possível, medir:

- as florestas de pinus na saída de norte de SP (via Bandeirantes) mostram ponteiras ralas e de galhos desencontrados, exatamente como as florestas de pinus na Escandinávia;

- os engenheiros florestais de Viçosa e de Piracicaba foram convocados pelas empresas do Vale do Rio Doce em MG para esclarecer qual a "doença" responsável pela calcinação e pelos disturbios de crescimento das árvores em inúmeras áreas florestais na regiāo, onde os sintomas também são de acidificação cumulativa;

- as imediaçóes do polo petroquímico de Camaçari e da fundiçăo de cobre Caraiba (norte de Salvador) a jusante dos ventos, estáo visivelmente stressadas pela queima e desaparecimento de vegetação e pela erosão generalizada, e a causa certamente é a acidez atmosférica, eventualmente agravada pela maresia;

- as populaçốes residentes na direção dos ventos provenientes das fábricas de celulose já sabem quando vai chover, ou quando mudou o vento, pois são obrigados a respirar um dos piores odores industriais (mercaptanas, H2S), que o digam os moradores de Porto Alegre, RS, de Mogi Mirim, de Jacaréí e Mogi das Cruzes, em SP, e de várias outras cidades.

Esta é uma visão parcial da situação. Há desafios científicos e políticos de primeira grandeza para que se compreenda e para que se reverta o processo: novas estratégias e novas práticas de informaçáo social; questóes regionais e internacionais; a avaliação ou previsão dos efeitos ainda não avaliados e dos processos latentes.

A acidificação somente seria revertida se fossem atendidas duas demandas bastante complicadas na atual conjuntura: a responsabilizaçăo dos prejuízos, e antes que seja muito tarde, uma reforma energética, uma inflexão marcante no equacionamento da produçáo e do consumo de combustíveis.

É neste rumo que pretendemos contribuir com este texto, e é nesta direção que convocamos os colegas pesquisadores e os setores da sociedade que se organizam ou que se organizarāo em defesa de seus direitos e de seus projetos e utopias.

\section{Resumo}

O processo de acidificação da atmosfera vem se intensificando em várias áreas geográficas no mundo e no Brasil, como decorrência do aumento da queima dos combustíveis fósseis e 
de alguns outros processos industriais. A determinaçäo das responsabilidades pelos prejurzos é um desafio cient́fico e político e a interrupçäo da formaçăo das " manchas ácidas" no país exige novas disposiçôes de pesquisa e de controle, além de uma reforma energética urgente e profunda.

\section{Abstract}

The acidification of the atmosphere due to growing fossil fuel combustion and some industrial processes towches more and more greographic areas in the world and in Brazil. The responsibilities for the losses and damages are delicate to establish, what represents a scientific and political challenge; and the reversion of this process requires new control and research patterns, including an urgent and deep energetic reform.

\section{Bibliografia}

BARRE, Remi. " Les pluies acides en Europe - un avenir écologique en forme de scénarios geopolitiques e scientifiques". In: revista Futuribles, juin 1985, p. 55-71.

CHARNOCK, Garry. "Acid test for Scottish Loch". In: revista World Water, jan-feb 1985, p. 32-3.

COMMONER, Barry. Energias Altermatipas. Rio de Janeiro, Record, 1987.

CORTES, Ilka e dos ANJOS, J.R. "Investigaçăo e estudo dos efluentes da mineração na sub-bacia do rio Sangäo, SC ${ }^{n}$. In: Anais do $2^{\circ}$ Encontro Nacional de Estudos sobre o Maio-Ambiente, org. Depto. Geografia/CCH/UFSC, Florianópolis, set. 1989, p. 206-14.

CRUZ, Humberto (coord.). " Lluria acida - impacto ambiental de las grandes instalaciones de combsustion' . Seminário realizado em Madrid, abril 1988. Federacion Amigos de la Tierra e Bur6 Europeo de Medio Ambiente. Miraguano Ediciones, Madrid, 1990.

EGMOND, N.D.van. "Air pollution as a result of the cmission from coal-fired power stations. Report PEO/Management Office for Energy Research, Utrecht, 1986.

FONSECA CESSAR, Sebastiăo. A interceptacto e altorafóes na qualidade da dgrua da chuva atrapts do dossel florestal an floresta lati-foliada tropical. Tese de mestrado, Depto de Botânica, UFRJ, Rio de Janeiro, dez. 1986.

HAMMOND, Allen (editor-in-chief). " World Resources - Aguide to the Global Evwironment - 1990/91. World Resources Institute with UNEP/UNDP, Oxford University Press, Oxford, 1990.

HELLER, Barbara. "A morte vem do céu" . In: revista Sala de Aula, s/d, p. 21.

HUMERES, Eduardo (Depto. Química, UFSC). "A chuva que queremos" . In: revista Ciéncia Hoje, vol. 11, no 62, março 1990, p. 63-5.

JA (jornal diário Porto Alegre, RS). Entrevista com o presidente da Agapam - Associação Gaucha de Proteção do Ambiente, 30/06/90.

KOHLER, P. " Les grande sources d'cnergie, Hachetre, Paris, 1985.

LAST, F. " Consequencias para el medio anbiente de las emisiones originadas por los combustibles fosiles. In: Cruz (coord), cit., 1990, p. 23-47. 
LOCH, Ruth E.M. " A exploraçăo carbonifera e a degradaçăo ambiental em Crisciúma de 1956 a 1978" . In: Anais do $2^{\circ}$ Encontro Nacional de Estudos sobre o Meio Ambiente. Citado, 1989 , p. 229-235.

MINC, Carlos. "O ambiente destruido do socialismo autoritário". In: jornal Folsa de Säo Paulo, 09/08/1990.

PENNAFIRMe, Marcia. " Poeira tóxica envolve atmosfera da Grande Vitória". In: Jormal do Brasil, 01/07/1990, p. 18.

PERSSON, Göran (chairman Expert Group of Environment 82 Commitee Swdish Ministry of Agriculture). " Acidification Today and Tomorrow - a Swedish Study prepared for the 1982 Stockholm Conference on the Acidification of the Environment", NSEPB, Solna, 1982.

PRIVAT, Pascal, et. al. "The Alps: Storm Signals" . In: revista Newsspeek, april 23, 1990, p. $42-5$ (obs. matéria de capa).

SEVÁ, Oswaldo e FERREIRA, L. (org.). O projeto da Termo-Elttrica de Paulinia, SP: a questão energttica e a degradaç̆öo sócio-ambiental. NEPAM/Unicamp, 1989.

TER-STEPANIAN. " Beginning of Technogene" . In: Bulletin of International Association of Enginnering Geology. n. 82, Paris, 1988.

THURNBERG, BÖ (editor). "Acidification and Air Pollution - a briff guide. National Swedish Environment Protection Board, Solna, 1987.

TIEZZI, Enzo. Tempos Históricos, Tempos Biologgicos. São Paulo, Nobel, 1988.

TUFFANI, Mauricio. "Chuva ácida não é controlada em São Paulo". In: jornal Folsa de São Paulo, Caderno Ciência, 13/04./1990.

Entidades estrangeiras de mobilizaçāo e de pesquisas sobre a acidez

Suécia: Swedish NGO Secretariat un Acid Rain - Miljövard, Valgatan 22 S 411. Box 33031 S400 33, 16 Göteborg, Sweden. Edita a revista Acid News, editor Christer Agren.

Holanda: RijksInstitut voor Volksgezondheid en Milieuhygiene RIVM (National Institute of Public Health and Environmental Hygiene) PO Box 1, 3720 BA Bilthoven, The Nederlands. Pesquisadores sobre acidez:ERISMAN, J-W., DE LEEUW, F. VAN AALST, Roel. Laboratory for Waste Materials and Emissions, resp. R. THOMAS.

Bélgica: C.E.E. DG XI - Service de Contrôle de la Pollution Atmospherique. 200, rue de la Loi 1049 Bruxelles. 